\title{
Second Life Application of Automotive Catalysts: Hydrodynamic Cavitation Recovery and Photo Water Splitting
}

\author{
Adrian Ciocanea ${ }^{1}$, Eugeniu Vasile ${ }^{2, *}$, Viorel Ionescu ${ }^{3}$, Florentina Iuliana Maxim ${ }^{4}$, \\ Cornelia Diac ${ }^{4}$, Cristina Miron ${ }^{5}$ and Serban N. Stamatin ${ }^{4,5}$ \\ 1 Hydraulics and Environmental Engineering Department, Power Engineering Faculty, Hydraulics, \\ University POLITEHNICA of Bucharest, 060042 Bucharest, Romania; adrian.ciocanea@upb.ro \\ 2 Department of Oxide Materials and Nanomaterials, Faculty of Applied Chemistry and Material Science, \\ University POLITEHNICA of Bucharest, 060042 Bucharest, Romania \\ 3 Department of Physics and Electronics, Ovidius University of Constanta, 900527 Constanta, Romania; \\ v_ionescu@univ-ovidius.ro \\ 4 3Nano-SAE Research Centre, University of Bucharest, 077125 Bucharest, Romania; \\ iuliana.maxim@3nanosae.org (F.I.M.); cornelia.diac@3nanosae.org (C.D.); serban@3nanosae.org (S.N.S.) \\ 5 Faculty of Physics, University of Bucharest, 077125 Bucharest, Romania; cristina.miron@fizica.unibuc.ro \\ * Correspondence: eugeniu.vasile@upb.ro; Tel.: +40-214-574-838
}

Received: 11 August 2020; Accepted: 25 September 2020; Published: 29 September 2020

check for updates

\begin{abstract}
A hydrodynamic cavitation method was used to maximize the effect of destructuration of a honeycomb monolithic support of a spent Selective Catalyst Reduction (SCR) catalyst $-\mathrm{V}_{2} \mathrm{O}_{5}-\mathrm{WO}_{3} / \mathrm{TiO}_{2}$-type-for extracting crystalline titanium and tungsten oxides from the cordierite surface. A high relative inlet pressure of $40 \mathrm{MPa}$ was applied to a divergent nozzle for obtaining high shear stresses of the submerged cavitating jets and intensive micro- and nano-jets and shock waves acting on the particle surface of the milled catalyst. Scanning Electron Microscopy (SEM) analysis indicated the compact morphology of the thin metal oxide layer at the surface of the cordierite support and the high content of $\mathrm{Ti}$ and $\mathrm{W}$ elements in the sample. Energy dispersive spectroscopy (EDAX) performed along with TEM investigations on different nano-zones from the sample established the elemental composition of $\mathrm{WO}_{3}-\mathrm{TiO}_{2}$ agglomerates separated after hydrodynamic cavitation processing and identified as independent nanocrystalline structures through Bright Field Transmission Electron Microscopy (BF-TEM) and High Resolution Transmission Electron Microscopy (HR-TEM) measurements. The tetragonal anatase phase of $\mathrm{TiO}_{2}$ and cubic phase of $\mathrm{WO}_{3}$ were established by both interplanar $d$ spacing measurements and X-ray diffraction analysis. The photoelectrochemical results showed the possible second life application of automotive catalysts.
\end{abstract}

Keywords: cavitation; nanocrystalline; catalyst; cordierite; HR-TEM; EDAX; photoelectrochemistry

\section{Introduction}

Selective catalyst reduction (SCR) catalysts proved to be an excellent technology for the reduction of nitrogen oxide $\left(\mathrm{NO}_{\mathrm{x}}\right)$ emissions in diesel exhausts, due to a wide window of operating temperatures, the durability of deactivation, and high conversion rate of $\mathrm{NO}_{\mathbf{x}}[1,2]$. Their low cost and enhanced performance in specific areas caused them to be recommended for integration in some diesel-powered light and heavy-duty vehicles [3-6].

A SCR catalyst is composed primarily of anatase $\mathrm{TiO}_{2}$ used as the catalyst carrier, $\mathrm{V}_{2} \mathrm{O}_{5}$ as the active component, and $\mathrm{WO}_{3}$ acting as a promoter for thermal stability of the catalyst and offering resistance to sulfur contamination. A conventional method of preparation for the supported $\mathrm{VO}_{\mathrm{x}}-\mathrm{WO}_{\mathrm{x}} / \mathrm{TiO}_{2}$ 
catalysts is by impregnation of soluble vanadium and tungsten oxide precursors onto the titania support. The supported vanadia and tungsten oxide phases consist of mono-oxo surface species of $\mathrm{VO}_{4}\left(\mathrm{O}=\mathrm{V}(-\mathrm{O}-\mathrm{Ti})_{3}\right)$ and $\mathrm{WO}_{5}\left(\mathrm{O}=\mathrm{W}(-\mathrm{O}-\mathrm{Ti})_{4}\right)$, respectively [7]. When $\mathrm{VO}_{4}$ monolayer coverage is exceeded, crystalline $\mathrm{V}_{2} \mathrm{O}_{5}$ nanoparticles (NPs) will be formed and also, $\mathrm{WO}_{3} \mathrm{NPs}$ can rise above the $\mathrm{WO}_{5}$ monolayer coverage [7]. The interaction between $\mathrm{WO}_{\mathrm{x}}$ active sites and the $\mathrm{TiO}_{2}$ layer will influence the distribution and morphology of $\mathrm{VO}_{\mathrm{x}}$ on the carrier, $\mathrm{VO}_{\mathrm{x}}$ being easily distributed on $\mathrm{TiO}_{2}$ adjacent to $\mathrm{WO}_{\mathrm{x}}$ sites [8].

The honeycomb-type monolithic support for the metal oxide species in the SCR catalyst is usually made of cordierite $\left(2 \mathrm{MgO}-2 \mathrm{Al}_{2} \mathrm{O}_{3}-5 \mathrm{SiO}_{2}\right)$. The oxides of vanadium and tungsten contribute to about $40 \%$ of the total cost of the SCR catalyst [9]. The commercial $\mathrm{V}_{2} \mathrm{O}_{5}-\mathrm{WO}_{3} / \mathrm{TiO}_{2}$ catalyst presents high tungsten $(\mathrm{W})$ content, of about $7-10 \mathrm{wt} . \% \mathrm{WO}_{3}$ by comparing with vanadium $(\mathrm{V})$ content of only $0.5-1.5 \% \mathrm{~V}_{2} \mathrm{O}_{5}[1,10]$.

Depending on the tungsten oxide concentration, calcination temperature, and synthesis method, $\mathrm{WO}_{3} / \mathrm{TiO}_{2}$ composites can be used as semiconductor layers in heterogeneous photocatalysts [11]. For example, $2 \% \mathrm{WO}_{3} / \mathrm{TiO}_{2}$ catalyst prepared by the sol-gel method with a calcination stage developed at $500{ }^{\circ} \mathrm{C}$ for $4 \mathrm{~h}$ represents a promising material for the solar photocatalytic treatment of water contaminated by pesticides [12]. This sol-gel compound showed homogenous incorporation of $\mathrm{WO}_{3}$ clusters on the anatase $\mathrm{TiO}_{2}$ surface, with $\mathrm{TiO}_{2}$ nanoparticles of about $20 \mathrm{~nm}$ in diameter. $\mathrm{WO}_{3}$ species anchored to the crystalline $\mathrm{TiO}_{3}$ (edge, corner, and facets) improved the photocatalytic activity by reducing electron-hole recombination, resulting in a more efficient transference of electrons between $\mathrm{TiO}_{2}$ and $\mathrm{WO}_{3}$ [12]. Electrospinning technique completed with heat treatment at $650-800{ }^{\circ} \mathrm{C}$ was applied to solutions containing $\mathrm{TiO}_{2} / \mathrm{WO}_{3}$ fibers and conducted to the deposition of semiconductor thin films with good photoactivity [13]. $\mathrm{WO}_{3} / \mathrm{TiO}_{2}$ nanoporous layers obtained by a micro-arc oxidation technique proved also to be a narrow bandgap photocatalyst which could decompose environmental pollutants under visible irradiation [14].

As a consequence of the limited chemical lifetime for the SCR catalyst (usually about 3 years), a regeneration process involving a chemical and/or heat treatment is often considered in order to extend this lifetime, often doubling it [15]. Even so, almost all of the deactivated SCR catalyst, after several regeneration cycles, ends up as waste and is disposed of in landfills. Starting in 2014, the spent SCR catalyst was classified in China as a hazardous solid waste [16]. Tungsten poses potential risks to human health and the environment, being classified by the U.S. Environmental Protection Agency (EPA) as an emerging contaminant [17]. The impact of $\mathrm{W}$ on soil and plants may represent a potential risk for human health by consumption of tungsten-polluted fauna and flora in the food chain. Therefore, the environmental and economic aspect of this waste product must be evaluated properly. In order to avoid soil contamination with the entire metallic residue coming from this catalyst waste and to recycle a part of it, a simultaneous processing strategy based on the recovery of valuable metals and regeneration of the rest of the spent catalyst must be considered [18]. The crystalline structure of $\mathrm{TiO}_{2}$ must be preserved after treatment to reuse the processed residue as a new catalyst carrier [18].

Various pyrometallurgical/hydrometallurgical treatment techniques have been employed to recover the valuable metals from SCR catalyst waste. A pressure leaching process using caustic soda was used by I-H Choi et al. [19] for direct extraction of W and V from the spent SCR catalyst. A soda roasting process offered the possibility of increasing the leaching efficiency of tungsten from catalyst waste by increasing $\mathrm{Na}_{2} \mathrm{CO}_{3}$ content, roasting time, and temperature [20]. Another hydrometallurgical technique for the recovery of $\mathrm{W}$ in the form of synthetic $\mathrm{CaWO}_{4}$ through roasting, acidic decomposition (using an $\mathrm{HCl}$ solution), leaching (with $\mathrm{NaOH}$ ), and precipitation was also reported as a successful SCR waste processing method [21]. However, these methods are considered as unsustainable methods with long process flow, high energy consumption, and heavy waste emission [22]. Due to strict environmental regulation policies [23], it is highly desirable to develop an effective and green technique for spent SCR catalyst disposal [24]. 
A number of research studies reported successful application of hydrodynamic cavitation technique (HDC) for physical and chemical processing of different aqueous solutions such as wastewater treatment [25,26], water disinfection [27,28], modifications/improvements in physical properties of the polymers [29], and highly efficient rehydration of powders [30,31]. A few studies have been oriented on the synthesis of nanostructured catalysts through hydrodynamic cavitation, like the synthesis of nanostructured titania [32], synthesis of metal oxide catalysts with a grain size of 1-10 nm supported on silica (as a high surface area material) [33], or aggregation of ultra-fine scheelite $\left(\mathrm{CaWO}_{4}\right)$ particles [34].

For most of the experiments presented above, cavitation was generated through an orifice plate, and the cavitation nuclei are produced in an orifice flow by the gas released due to the pressure reduction or by the partial vaporization of liquid [35]. K. Sampath Kumar and V. S. Moholkar [35] designed a new type of HDC reactor based on a converging-diverging nozzle with the purpose of generating the pressure variation necessary for imposing the radial motion of cavitation bubbles, a phenomenon theoretically described by V. S. Moholkar and A. B. Pandit [36].

In this paper, a test chamber for hydrodynamic cavitation with diverging nozzles is used for the extraction of crystalline titanium and tungsten oxides from the cordierite surface of the $\mathrm{V}_{2} \mathrm{O}_{5}-\mathrm{WO}_{3} / \mathrm{TiO}_{2}$ spent catalyst. High values for shear forces obtained by the ignition of bubble clouds in cavitation jets were obtained for an erosion effect at the particle surface. The hydrodynamic cavitation is evidenced by elemental analysis. The second life application is proven by the photoelectrochemical activity under illumination.

\section{Experimental}

\subsection{Chemical Composition}

Mineralization was used to determine the quantity of tungsten (W), titanium (Ti), and vanadium (V). A Milestone Microwave Labstation for Synthesis (Bergamo, Italy) was used for the mineralization. The samples were in liquid and solid states. The solids were prepared from a spent catalyst. The catalyst was milled very finely for mineralization synthesis. The sample for the microwave contained $0.5 \mathrm{~g}$ dispersed in $12 \mathrm{~mL}$ of aqua regia. Aqua regia was prepared with $9 \mathrm{~mL}$ of $\mathrm{HCl}(35 \%)$ and $3 \mathrm{~mL}$ of $\mathrm{HNO}_{3}$ $(65 \%)$. Hydrochloric acid and nitric acid were purchased from Lachner (Neratovice, Czech Republic). The program was set to $180^{\circ} \mathrm{C}$ for $30 \mathrm{~min}$. The volume was adjusted to $30 \mathrm{~mL}$ with ultrapure water after the mineralization. Ultrapure water $(>18.2 \mathrm{M} \Omega \times \mathrm{cm})$ was supplied by the Milli-Q Direct $\mathrm{Q}$ System (Burlington, MA, USA).

The quantity of $\mathrm{W}, \mathrm{Ti}$, and $\mathrm{V}$ was determined by inductively coupled plasma-optical emission spectrometry (ICP-OES-Perkin Elmer, Avio 200, Waltham, MA, USA). Multi-element Calibration Standard 5 (PerkinElmer Inc., Waltham, MA, USA) was used to determine the W quantity. An ICP Calibration Standard Quality Control (XVI) - 21 components, supplied by CPAChem (Stara Zagora, Bulgaria), was used to construct the calibration curve for Ti and V. UV-vis (Jasco V550, Tokyo, Japan) was used to determine the presence of titanium complexes from solutions.

\subsection{Structural and Morphological Characterization}

The crystalline phases existing in the SCR waste powder were investigated with a PANalytical $X^{\prime}$ Pert PRO MPD Powder Diffractometer (PANalytical, Almelo, The Netherlands). CuK $\alpha$ radiation (wavelength $1.5406 \AA$ ) and Bragg-Brentano diffraction geometry were employed here.

A scanning electron microscope (SEM) Quanta Inspect F (FEI-Philips, Hillsboro, OR, USA) working at an acceleration voltage up to $30 \mathrm{kV}$ and equipped with an energy dispersion $\mathrm{X}$-rays spectrometer (EDAX, $132 \mathrm{eV}$ resolution at $\mathrm{Mn} \mathrm{K} \alpha$ ) was used to determine the surface morphology and elemental composition of a small sample of cordierite covered with metallic oxides, obtained from the waste SCR catalyst before HDC treatment. SEM samples were covered with a very thin gold layer to obtain an optimum contrast during investigations. 
A transmission electron microscope (TEM) model Tecnai G2 F30 S-Twin, (FEI-Philips, Hillsboro, OR, USA) operated at an acceleration voltage of $300 \mathrm{keV}$ and equipped with an energy dispersive X-ray spectrometer (EDAX) was used to investigate the microstructure and composition of nanometric-sized crystalline agglomerates obtained after the HDC processing of SCR waste powder. Small portions of the catalyst sample were taken and ground in an agate mortar. A small amount of such a fine powder was dispersed in ultrapure water, then subjected to ultrasound processing to obtain a homogeneous dispersion of the sample particles in water. A drop of this dispersion was deposited onto a thin amorphous carbon film supported by a copper TEM grid. After drying, the prepared grid was inserted into the TEM holder to investigate the sample under transmission electron microscopy.

\subsection{Hydrodynamic Cavitation Method}

Hydrodynamic cavitation was compared to the acoustic cavitation and selected as the method for achieving the aim of the research due to higher bubble jet density [37], low influence of the liquid composition on the induced shear forces during bubble collapse at the surface of the target particle [38], and ease to be scaled up.

The experimental setup is presented in Figure 1a, where a cavitation jet system provides a maximum upstream pressure of $40 \mathrm{MPa}$ to a test chamber. The hydrodynamic conditions for obtaining high shear forces for submerged cavitating jets were settled down by using a divergent conic nozzle with the throat diameter of $0.5 \mathrm{~mm}$ (see Figure 1b). For these conditions, one obtained intense microand nano-jets and shock waves acting on the particle surface of milled catalyst $[39,40]$. The tests were performed for $50 \mathrm{~g}$ of ground material recovered from a fracture of a spent SCR catalyst (see Figure 2a). The best results were obtained when keeping the upstream pressure constant at $40 \mathrm{MPa}$ and atmospheric pressure at the outlet of the test chamber. A constant flow rate of $0.5 \mathrm{~L} / \mathrm{min}$ for the plunger pump was settled down for all the tests. Four rounds of hydrodynamic cavitation were performed. Each round consisted of 50 submerged water jets induced in the test chamber. A volume of $1.5 \mathrm{~L}$ of biphasic fluid was obtained at the end of each round and subjected to sedimentation; the evolution of the aqueous solutions is presented in Figure $2 \mathrm{~b}$. The sediment obtained after one cavitation round was introduced for the next one working at the same parameters. Therefore, the particles of the spent catalyst were subjected to 200 cycles of hydrodynamic cavitation.

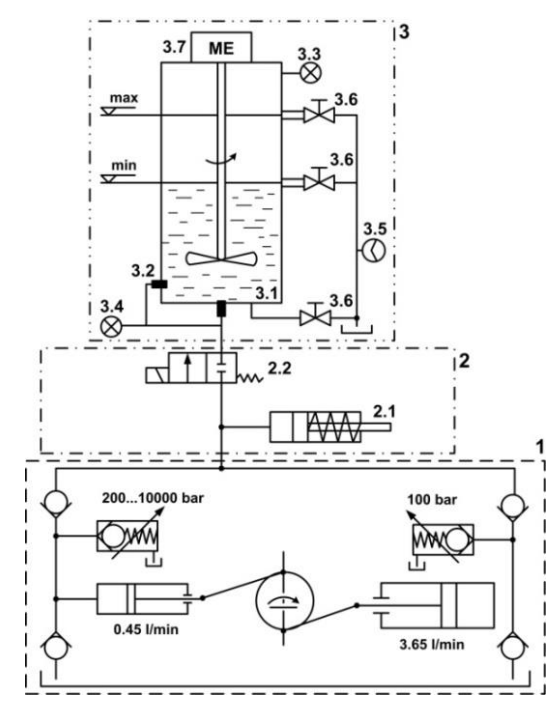

(a)

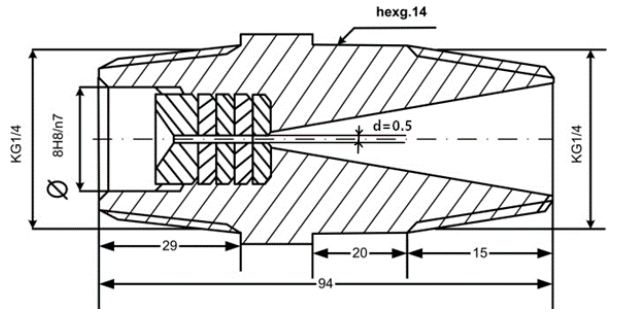

(b)

Figure 1. (a) Cavitation jet system (1-Plunger pump system; 2-Pressure distribution system: 2.1-Accumulator, 2.2-Electric distributer; 3-Test chamber: 3.1 and 3.2-Nozzle, 3.3-Low pressure transducer, 3.4-High pressure transducer, 3.5-Flow indicator, 3.6-Valve, 3.7-D.C. motor and propeller) and (b) Cavitation nozzle. 


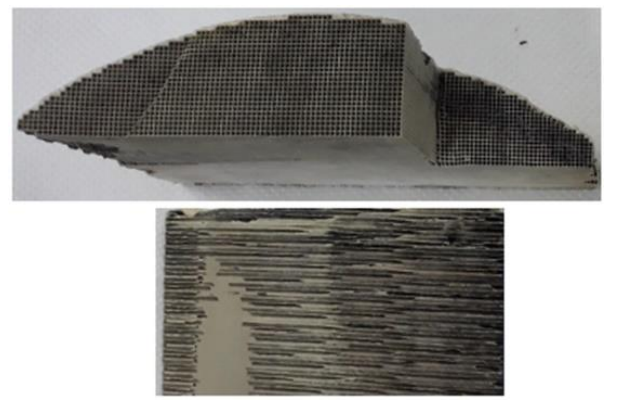

(a)

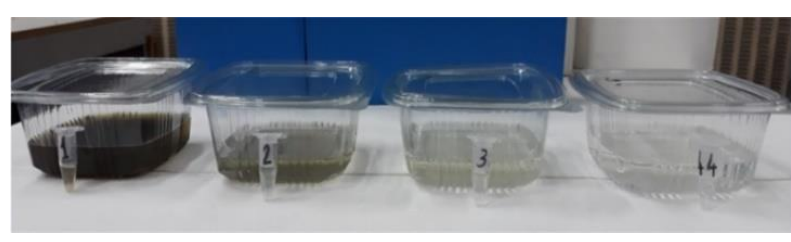

(b)

Figure 2. (a) Selective catalyst reduction catalyst fracture; (b) Liquid sample after four hydrodynamic cavitation stages. The initial cavitation contained $50 \mathrm{~g}$ of the catalyst and resulted in a dark liquid (1); the sediment from the first cavitation was subjected to another cavitation and resulted in a dark grey liquid (2); the sediment from the second cavitation was subjected to another cavitation and resulted in a light grey liquid (3); the last cavitation contained only the sediment from the third cavitation and resulted in a transparent liquid.

During the hydrodynamic process at elevated values for the upstream pressure, erosion and mechanical shocks simultaneously produce a high quality of fractions for recovery compared with other mechanical methods e.g., attrition scrubbing [41].

\subsection{Electrochemical Measurements}

Hydrogen evolution reaction was performed in a photoelectrochemical cell (PECC-2, ZAHNER-Electrik GmbH \& CoKG, Kronach, Germany) equipped with a transparent working electrode (18 mm optical window diameter) and Voltalab electrochemical workstation (Voltalab, PGZ 301, Radiometer Analytical, Villeurbanne, France). A mercury lamp (PS-2 Mercury Lamp 100 W/DC, VanGuard, Guangdong, China) was used as a light source and positioned in front of the transparent working electrode at 6-7 cm. Fluorine-doped tin oxide plates (FTO, $7 \Omega \mathrm{cm}^{-2}$ ) purchased from Sigma-Aldrich, St. Louis, MO, USA, (\#735167-1EA) served as a working electrode support. The counter and the reference electrodes were a platinum wire and $\mathrm{Ag} / \mathrm{AgCl}$, respectively. The reference electrode potential was measured against an in-house built reversible standard hydrogen electrode (SHE; Supplementary Material, Figure S1). The average measured potential was $(-452 \pm 0.736) \mathrm{mV}$ vs. SHE. All the electrochemical potentials hereinafter are referenced versus SHE.

Working electrodes were manufactured by spraying $30 \mathrm{~mL}$ of catalyst solution on FTO plates at $100{ }^{\circ} \mathrm{C}$ from a vertical position at approx. $10 \mathrm{~cm}$ height. The equipment used was an airbrush $(5 \mathrm{~mm}$ nozzle) connected at an air compressor (AF186 Mini Air Compressor, HSENG, Zhejiang, China) with a pressure of 2 bar. The electrochemical measurements were carried out in $0.1 \mathrm{M} \mathrm{K}_{2} \mathrm{SO}_{4}$. The applied potential is between -350 and $-1150 \mathrm{mV}$ vs. SHE with a repeated on/off irradiation cycles ( $5 \mathrm{~min}$ : $1 \mathrm{~min}$ in the dark to stabilize the current followed by $30 \mathrm{~s}$ on/30 s off cycles).

\section{Results and Discussions}

The X-ray diffraction pattern for the pristine SCR, that is before the hydrodynamic cavitation, is presented in Figure 3. The strongest diffraction peak was at $2 \theta=10.48^{\circ}$. Most of the peaks were associated with the orthorhombic phase of $\mathrm{Mg}_{2}\left(\mathrm{Al}_{4} \mathrm{Si}_{5} \mathrm{O}_{18}\right)$ (cordierite), based on ICDD PDF \#01-076-6037. The tetragonal anatase $\mathrm{TiO}_{2}$ was also identified in the diffraction spectrum. The main crystalline peak at $2 \theta=25.37^{\circ}$ was attributed to (101) in line with ICDD PDF \#04-002-2751. The broad, low intensity diffraction peak at $2 \theta=23.63^{\circ}$ ( $3.75 \AA$ interplanar distance) suggests the presence of a small amount of $\mathrm{WO}_{3}$ cubic tungsten oxide (ICDD PDF: \#00-046-1096). The crystalline phase for $\mathrm{V}_{2} \mathrm{O}_{5}$ was not detected in the XRD pattern due to a very low amount of this oxide in the SCR catalyst 
composition. It was reported that $\mathrm{V}_{2} \mathrm{O}_{5}$ loadings between 0.5 and $2 \mathrm{wt} . \%$ in a spent SCR catalyst did not affect $X R D$ patterns in terms of particle size and crystalline phase [42].

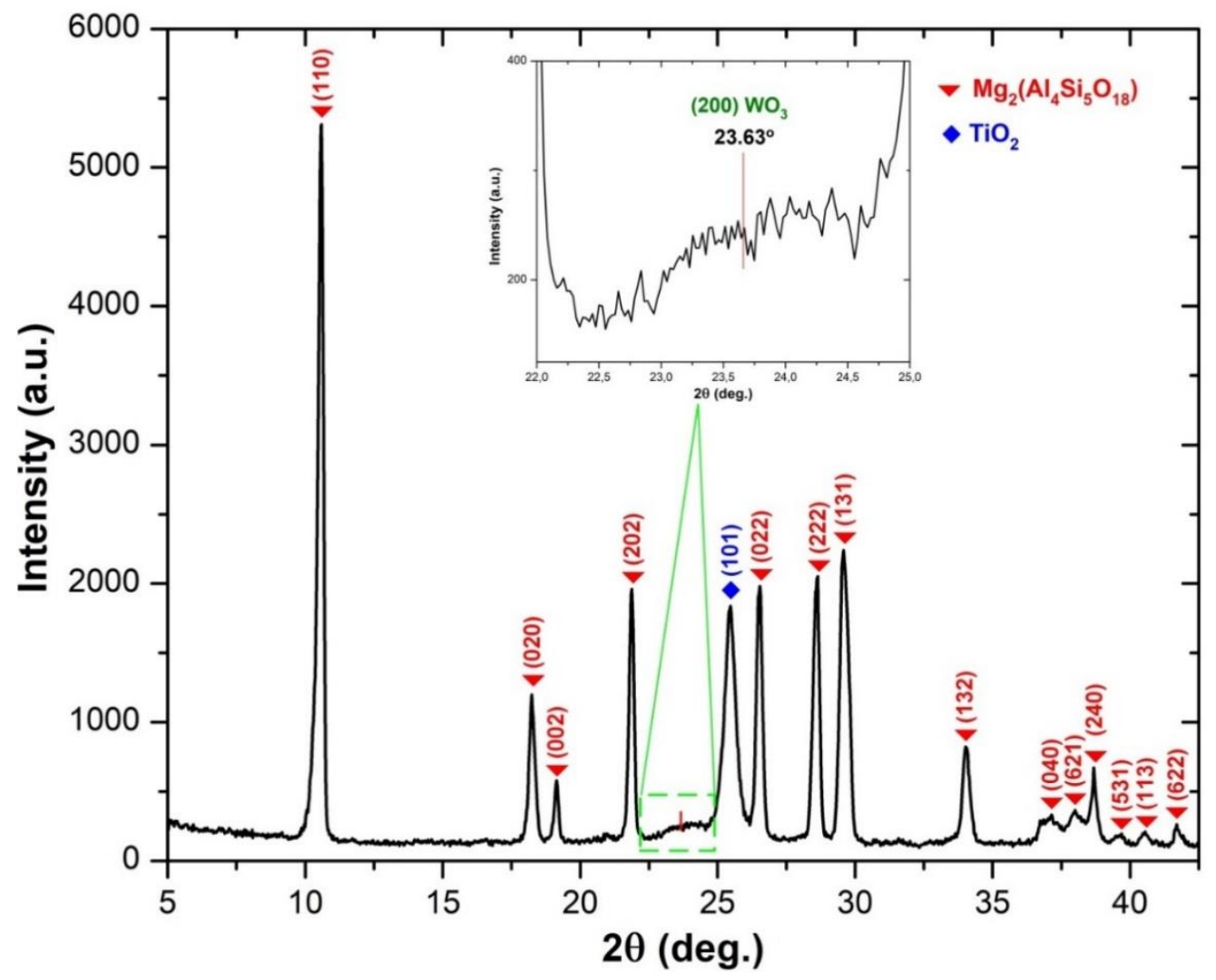

Figure 3. XRD spectra for a sample of a spent SCR powder.

Marberger et al. [10] investigated thermally aged $\mathrm{V}_{2} \mathrm{O}_{5} / \mathrm{WO}_{3}-\mathrm{TiO}_{2}$ catalyst samples (after treatment at $600{ }^{\circ} \mathrm{C}$ ), with $\mathrm{V}_{2} \mathrm{O}_{5}$ loading between 1.7 and $3.5 \mathrm{wt}$ \% by XRD. No $\mathrm{V}_{2} \mathrm{O}_{5}$ crystalline peaks could be detected in any of their spectra, but a weak $\mathrm{WO}_{3}$ peak having identical shape with the one identified here in the inset image from Figure 3 (between the same $2 \theta$ values) was evident in the spectrum registered for the aged sample with $2.6 \mathrm{wt} . \% \mathrm{~V}_{2} \mathrm{O}_{5}$. Below $2.3 \mathrm{wt} . \% \mathrm{~V}_{2} \mathrm{O}_{5}, \mathrm{WO}_{3}$ was not visible in the XRD patterns.

The metal concentration of Ti, $\mathrm{W}$, and $\mathrm{V}$ was determined by inductively coupled plasma-optical emission spectroscopy (ICP-OES) prior to acid digestion. The initial catalyst was found to contain 2.1, 1.4, and $3.2 \mathrm{~g} / \mathrm{kg}$ of $\mathrm{Ti}, \mathrm{W}$, and $\mathrm{V}$, respectively. Cordierite components, such as $\mathrm{Al}, \mathrm{Mg}$, and $\mathrm{Si}$, were removed from the ICP-OES analysis due to the high concentration. The reader should bear in mind that cordierite is the catalyst support and it has no catalytic activity.

Figure 4 shows the SEM and EDX analysis of an SCR (see Figure 4). Small metal oxide agglomerates of metal oxides were found to be deposited on the surface of cordierite domain. The oxide film thickness was estimated at $20 \mu \mathrm{m}$. It is well-known that $\mathrm{TiO}_{2}$ is used as a supporting catalyst to enhance catalytic performance $[20,42,43]$. EDX compositional investigations performed on the cordierite micro-area (morphologically identified in Figure 4a,b) indicated the presence of cordierite elements: $\mathrm{Si}, \mathrm{Al}$, and $\mathrm{Mg}$, as we can see in Figure 4c,d. Tungsten was not detected in these spectra, but a small quantity of Ti and Fe could be observed here. Fe percentage in the spent catalyst was reported to be 10 times higher than in the fresh one [44]. The presence of Fe in the catalyst is toxic and may significantly reduce its catalytic activity [45]. The EDX spectrum for film micro-area, presented in Figure $4 \mathrm{~d}$, revealed the presence of $\mathrm{Ti}$ element (at about $31.4 \mathrm{wt} . \%$ ) and also the presence of $\mathrm{W}$ at over $6 \mathrm{wt} . \%$. 


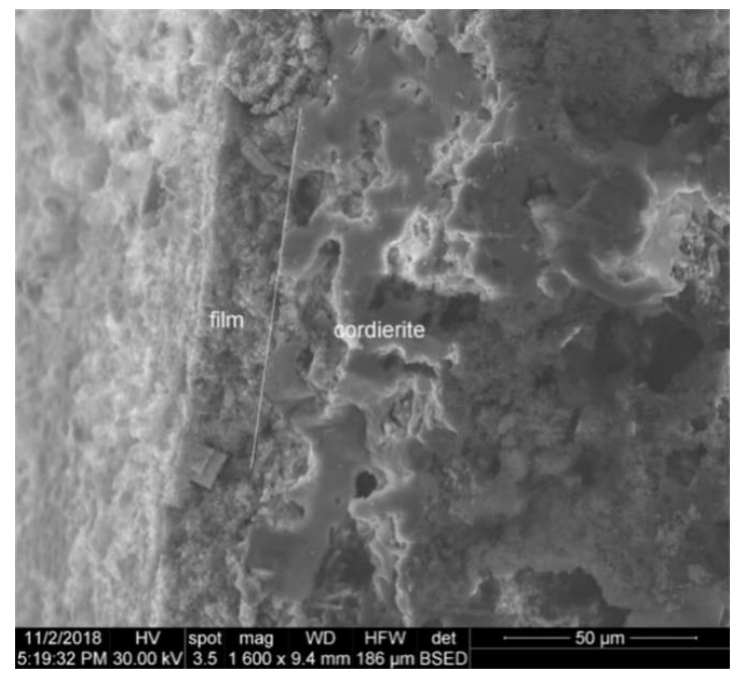

(a)

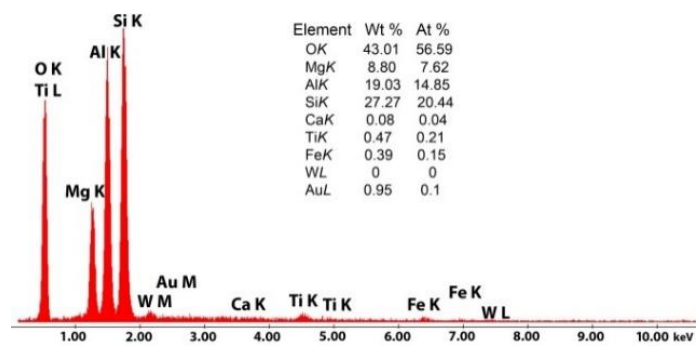

(c)

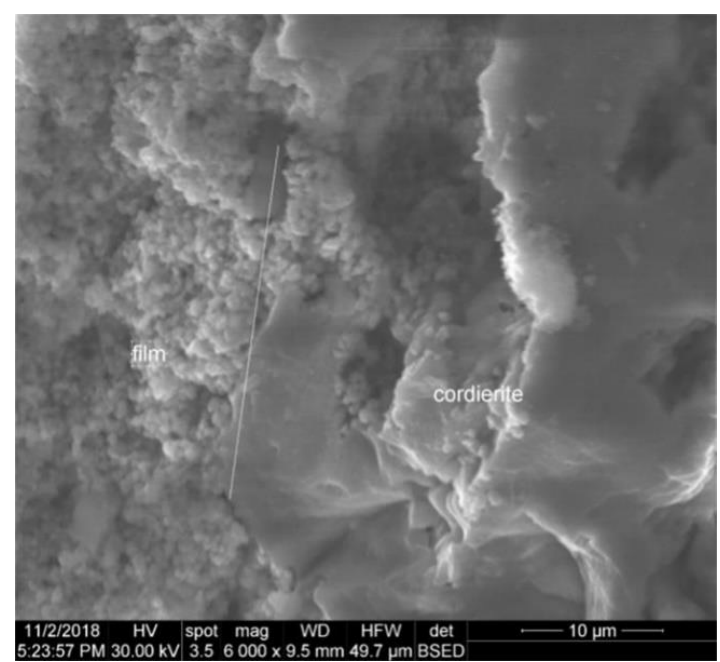

(b)

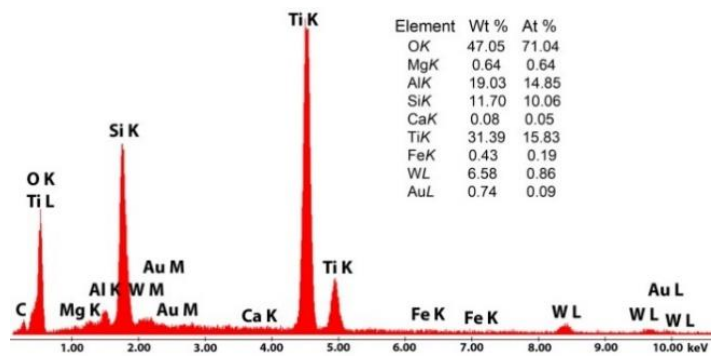

(d)

Figure 4. SEM secondary electron image (SEI) micrograph of spent catalyst sediment at a scale bar of: (a) $50 \mu \mathrm{m}$ and (b) $10 \mu \mathrm{m}$, and their associated EDX investigations along the cordierite (c) and catalyst film (d).

The $\mathrm{VK} \alpha$ line $(4.948 \mathrm{keV})$ is very close to the TiK $\beta$ line $(4.931 \mathrm{keV})$ in the EDX spectra. The main $\mathrm{VK} \alpha$ peak could not be detected without any doubt in our EDS investigations. It was reported that vanadium concentrations below $5 \mathrm{wt} . \%$ in a $\mathrm{TiO}_{2}-\mathrm{V}_{2} \mathrm{O}_{5}$ system are too low to be detected [44]. Chemical composition for a spent $\mathrm{V}_{2} \mathrm{O}_{5}-\mathrm{WO}_{3} / \mathrm{TiO}_{2}$ catalyst was analyzed by Wu et al. [43] through inductively coupled plasma optical emission spectrometry and indicated the following values: $51.66 \mathrm{wt} . \% \mathrm{Ti}$, 4.27 wt. $\%$ W, 0.54 wt. $\%$ Ca, 0.30 wt. \% V, and 0.28 wt.\% Fe. The EDX mapping feature has provided a higher level of analysis by automatically collecting spectrum and generating images with elemental distribution. Investigations performed on a small micro-area located at the film/cordierite interface are presented in Figure 5. A high-density distribution of Ti was detected along the granular part of the micro-area under investigation. A lower point density of $\mathrm{W}$ element was observed along the same portion of the film, formed by agglomerates of a few hundred nanometers in diameter. In the central part of the micro-area was established mostly the presence of cordierite elements: $\mathrm{Si}, \mathrm{Mg}$, and $\mathrm{Al}$, with a higher concentration than in the left granular part of the sample. Fe element was uniformly distributed along the entire area investigated. 


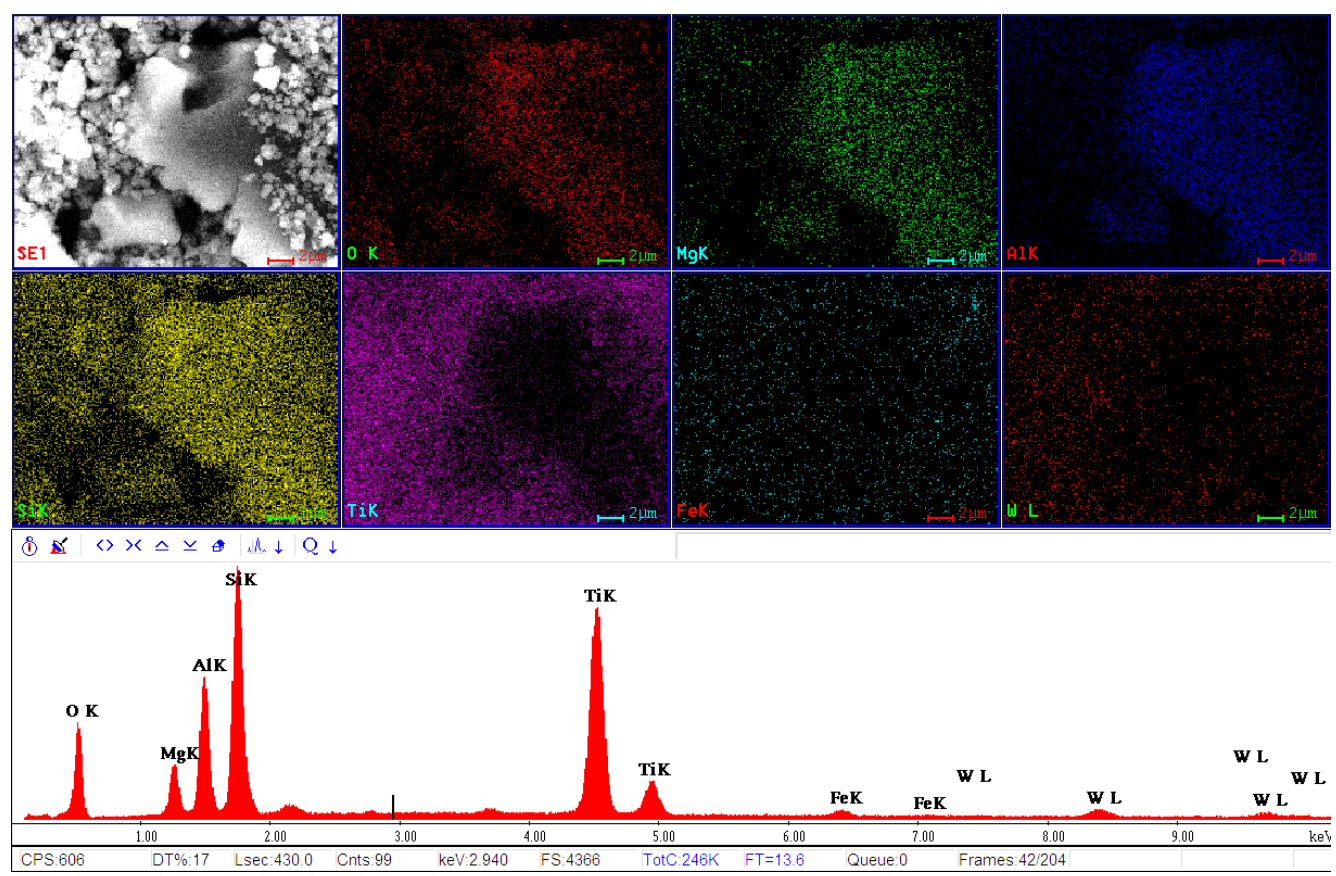

Figure 5. Energy dispersive spectroscopy elemental mapping image for $\mathrm{O}, \mathrm{Mg}, \mathrm{Al}, \mathrm{Si}, \mathrm{Ti}, \mathrm{Fe}$, and $\mathrm{W}$ along the SEM micro-area presented in the high-left corner and EDAX spectra for this spent catalyst sample. Scale bar is $2 \mu \mathrm{m}$.

Bright field transmission electron microscopy (BF-TEM) investigations were performed on a hydrodynamically processed catalyst sample to establish the separation of $\mathrm{Ti}$ and $\mathrm{W}$ oxides from cordierite. Two separated $\mathrm{WO}_{3}-\mathrm{TiO}_{2}$ aggregates like the one identified in Figure 6 were investigated by high-resolution TEM techniques. Figure 7a shows the presence of a large number of nanometric grains associated with $\mathrm{W}$ and Ti oxides having a diameter of about $16-25 \mathrm{~nm}$, identified in the nano-area with notation EDX2. I-H. Choi et al. [19] also reported from their TEM investigations of a spent SCR catalyst, processed through pressure leaching, the formation of a spherical type $\mathrm{TiO}_{2}$ particles with diameters close to $30 \mathrm{~nm}$ under the form of isolated aggregates. In the high-resolution TEM images presented in Figure 7b,d, we observed highly-ordered fringes spaced at 3.51 and $3.75 \AA$, corresponding to (101) and (100) crystallographic planes of tetragonal phase for $\mathrm{TiO}_{2}(\mathrm{ICDD}$ PDF: 04-002-2751) and cubic phase for $\mathrm{WO}_{3}$ (ICDD PDF: 00-046-1096), respectively.

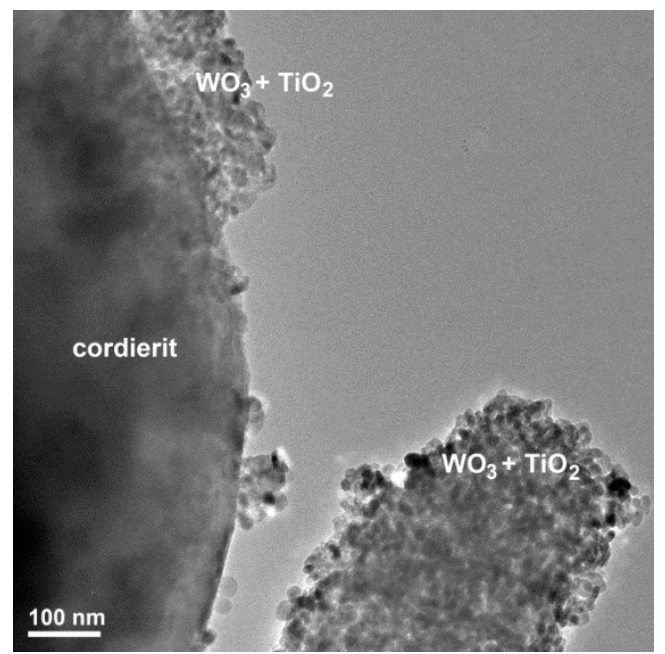

Figure 6. BF-TEM image of hydrodynamic cavitation processed catalyst sample. 

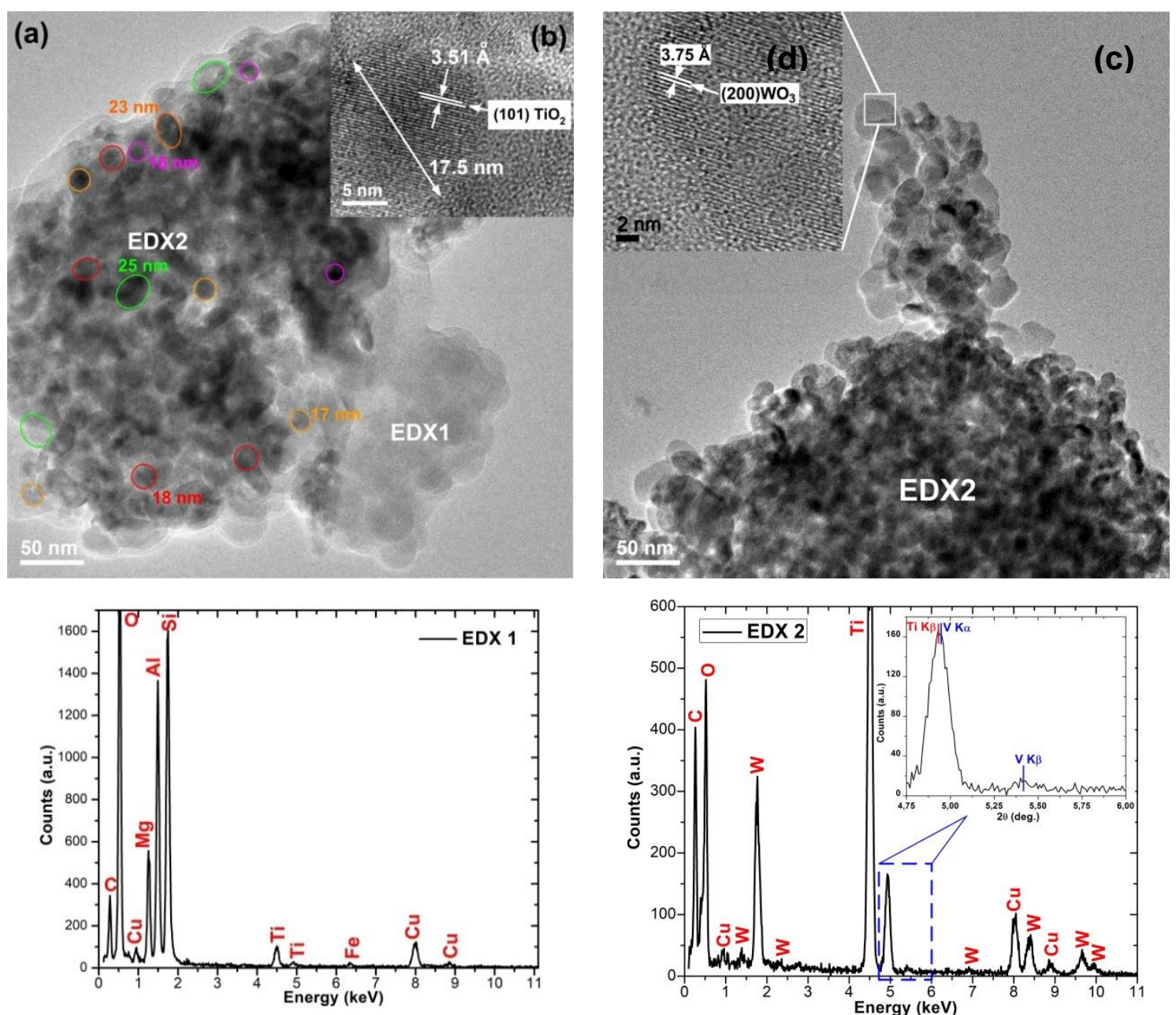

(e)

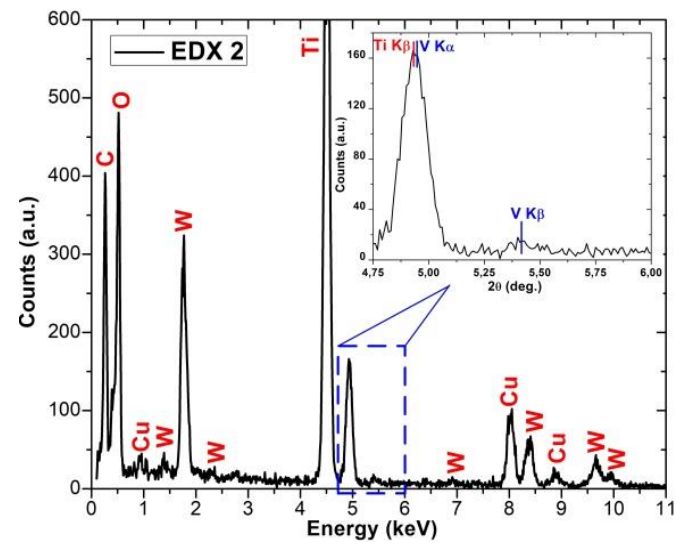

$(\mathbf{f})$

Figure 7. (a) Detailed BF-TEM image of a $\mathrm{WO}_{3}-\mathrm{TiO}_{2}$ agglomerate (EDX2) bounded with a small aggregate of cordierite (EDX1), (b) HR-TEM image of EDX2 nano-zone, (c) BF-TEM image of $\mathrm{WO}_{3}-\mathrm{TiO}_{2}$ agglomerate with (d) crystalline cubic phase identification for $\mathrm{WO}_{3}$ through HR-TEM analysis; $(\mathbf{e}, \mathbf{f})$ : EDAX spectra for the EDX nano-regions identified in $(\mathbf{b}, \mathbf{d})$.

Lee et al. [46] reported the existence of an excess quantity of $W$ in the fresh SCR catalyst as a dispersed amorphous $\mathrm{WO}_{\mathrm{x}}$ monolayer over the surface of $\mathrm{TiO}_{2}$. The $\mathrm{WO}_{\mathrm{x}}$ layer located on the $\mathrm{TiO}_{2}$ carrier can be divided into amorphous $\mathrm{WO}_{x}$ and crystalline $\mathrm{WO}_{3}$, and the appropriate amount of amorphous $\mathrm{WO}_{x}$ can promote the dispersion of moderately distorted vanadium species and prevent the formation of isolated vanadium oxo sites [47]. However, excessive amorphous $\mathrm{WO}_{x}$ will squeeze its neighboring vanadium species and lead to $\mathrm{VO}_{x}$ aggregation or the formation of crystalline $\mathrm{V}_{2} \mathrm{O}_{5}$ [48].

The EDX investigations showed the presence of cordierite elemental components, with a small amount of Ti (see Figure 7e). A large amount of Ti and also an important quantity of W could be established in the nano-area EDX 2, without the presence of any cordierite layer elements (see Figure 7f). From the inset image presented in Figure $7 \mathrm{f}$, we could see that the $\mathrm{K} \beta$ spectral line of vanadium had a detectable intensity (at $5.43 \mathrm{keV}$ ), suggesting the presence of $\mathrm{VO}_{\mathrm{x}}$ species on the nano-area investigated, most probably in the amorphous state due to the neighboring presence of $\mathrm{WO}_{3}$ in the crystalline phase. Here, the spectral presence of $C$ was associated with the amorphous carbon thin film of the TEM grid.

The initial cavitation was divided into $\mathrm{C} 1, \mathrm{C} 2$, and $\mathrm{C} 3$. For each cavitation, a solid and liquid sample was collected. The concentration of Ti, $\mathrm{W}$, and $\mathrm{V}$ determined in the solid and liquid resulted from the hydrodynamic cavitation. The digested initial sample contained 2.1, 1.4, and $3.2 \mathrm{~g} / \mathrm{kg}$ of Ti, W, 
and $\mathrm{V}$, respectively (Table 1). In the main tank, $50 \mathrm{~g}$ of catalyst was placed initially. Every cavitation cycle consisted of 50 submerged water jets (see Experimental Section 2.3) resulting in $0.75 \mathrm{~g}$ of sediment in the reservoir (see Figure 1). The calculated recovery rate was determined by dividing the metal mass in the sediment and liquid (determined from the metal concentration in Figure 8) to the metal mass in the initial sample. The overall efficiency was $44.7 \%, 46.2 \%$, and $11.8 \%$ for $\mathrm{Ti}, \mathrm{W}$, and $\mathrm{V}$, respectively. To the show the economic viability, we used the solution that resulted after the 3rd cavitation without further treatment as the semiconductor source (vide infra). The reader should bear in mind that the collected sediments can be used in other applications that require metal concentrations below $1 \mathrm{wt} . \%$.

Table 1. Metal concentration of the solid fraction in the initial and after the first (C1), second (C2), and third (C3) cavitation.

\begin{tabular}{cccc}
\hline Sample Identification & $\mathrm{Ti}[\mathrm{g} / \mathbf{k g}]$ & $\mathrm{W}[\mathrm{g} / \mathbf{k g}]$ & $\mathbf{V}[\mathrm{g} / \mathbf{k g}]$ \\
\hline initial catalyst & 2.1 & 1.4 & 3.2 \\
\hline first cavitation-C1 & 43.8 & 20.6 & 7.5 \\
\hline second cavitation-C2 & 3.4 & 2.3 & 1.7 \\
\hline third cavitation-C3 & 2.0 & 1.41 & 0.6 \\
\hline
\end{tabular}
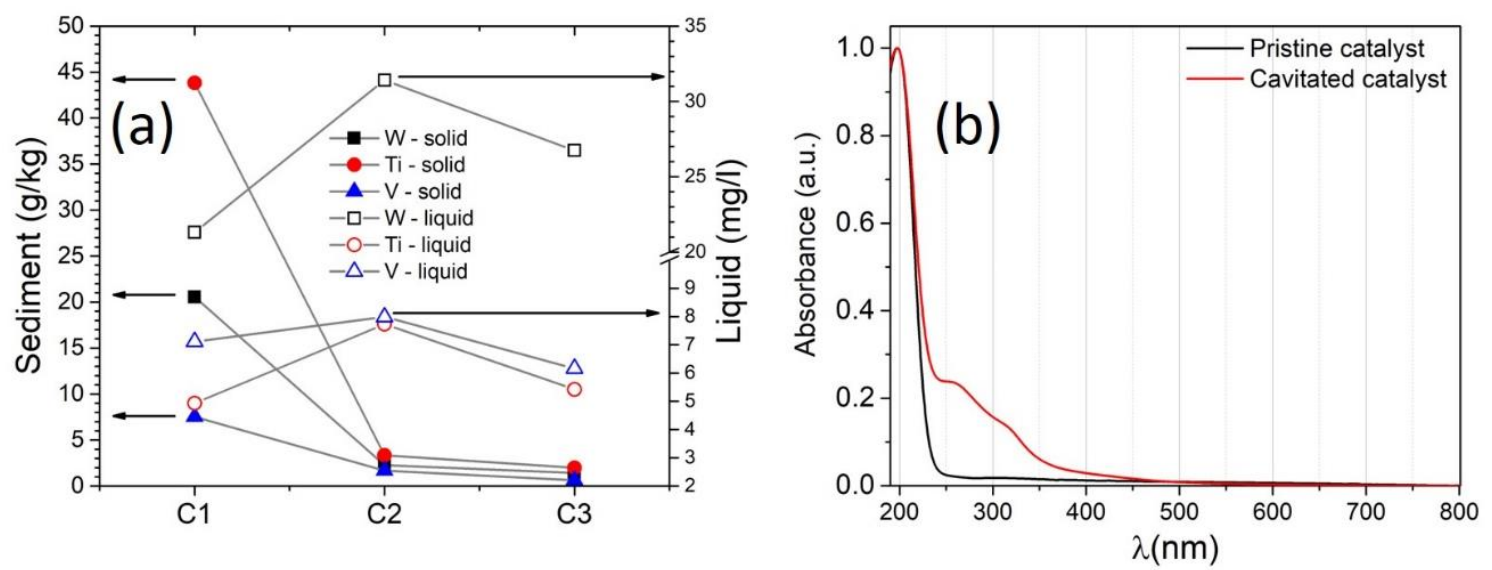

Figure 8. (a) The evolution of W (black squares), Ti (red circles), and V (blue triangles) in the sediments (solid fill) and liquid (no fill) as determined by inductive coupled plasma-optical emission spectroscopy; (b) UV-vis of the pristine catalyst and the cavitated catalyst.

Figure 8a shows the concentrations determined by ICP-OES in the sediment. A coarse separation takes place in the initial cavitation. The highest metal concentration in the liquid was determined in the second cycle. The presence of $\mathrm{Ti}, \mathrm{W}$, and $\mathrm{V}$ in the liquid called for a UV-vis characterization. Figure $8 \mathrm{~b}$ showed a flat absorption behavior of the pristine catalyst. The cavitated catalyst showed an increased absorption between 250 and $350 \mathrm{~nm}$. Two distinct features at 270 and $320 \mathrm{~nm}$ resemble the semiconductor behavior of $\mathrm{TiO}_{2}$ and $\mathrm{WO}_{3}$, respectively.

UV-vis and ICP-OES showed that there was a large amount of $\mathrm{W}, \mathrm{Ti}$, and $\mathrm{V}$ oxides present in the liquid, which can be used to carry out photoelectrochemical experiments. Figure 9 shows the photoelectrochemical experiments from -350 to $-1150 \mathrm{mV}$ vs. SHE. Protons are expected to be reduced to hydrogen gas at potentials below $-350 \mathrm{mV}$. The current was constant until the samples were illuminated and generated a photocurrent. The largest photocurrent was obtained at $-350 \mathrm{mV}$ with almost $0.5 \mu \mathrm{A}$. However, the photocurrent does not increase and decrease in the well-known rectangle shape, which suggests that there is another reaction. This is an indication that the electrode undergoes corrosion. Only at $-650,-750$, and $-850 \mathrm{mV}$ the generated photocurrent is equal to the decaying photocurrent. The electrode undergoes anodic overshoot when illuminated and cathode undershoot when the lamp was turned off at potentials more negative than $-850 \mathrm{mV}$. This is a clear indication 
that the potentials are too negative and the oxides undergo partial or complete reduction. All in all, the catalyst clearly showed its photoelectrochemical potential to act as a photo-substrate to split water. Nevertheless, the use of a co-catalyst to make use of the photogenerated electron-hole is needed.

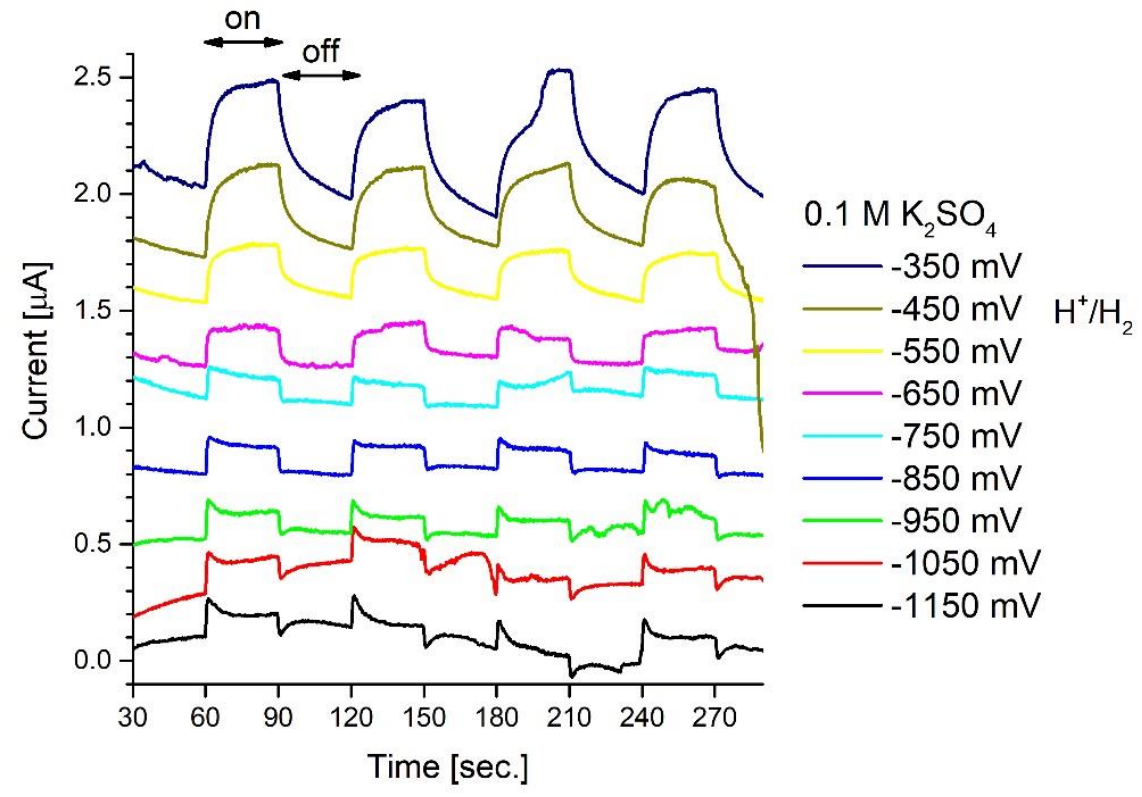

Figure 9. Photoelectrochemical experiments in $0.1 \mathrm{M} \mathrm{K}_{2} \mathrm{SO}_{4}(\mathrm{pH}=6.8)$ from -350 to $-1150 \mathrm{mV}$ vs. SHE. The potential for the $\mathrm{H}^{+} / \mathrm{H}_{2}$ couple was determined at $-401 \mathrm{mV}$ considering a $\mathrm{pH}=6.8$. Illumination profile: $30 \mathrm{~s}$ light on and $30 \mathrm{~s}$ light off. All the experiments are stacked at a constant value of $0.2 \mu \mathrm{A}$ on the $y$-axis.

Automotive catalysts that use metal oxides as the active component are hard to recover due to their chemical inertness. Their low price decreases the incentive for their recovery. Therefore, such automotive catalysts are rapidly considered waste. The environmental impact of the extensive use of metal oxide nanoparticles should be considered for their future applications [49,50]. T0he results presented in the work at-hand entangle hydrodynamic cavitation with photoelectrochemistry to generate a second-life application for metal oxide-based automotive catalysts. Our results showed that hydrodynamic cavitation can be used to increase the metal oxide concentration in the solid fraction by separating the cordierite from the metal oxide component. The sediment that resulted from the initial cavitation can be further used in applications that need a higher metal oxide concentration (e.g., cement-based paving for photocatalytic pavement).

Further treatment increases the metal oxide concentration in the liquid fraction with a remarkable colloidal stability over time. In this respect, the metal oxide solution can be used in sun-driven applications, such as photoelectrochemical water splitting. It has been recently reported that $\mathrm{TiO}_{2}$ and $\mathrm{WO}_{3}$ work in synergy to enhance the photoelectrochemical activity [51]. The photocurrents presented herein are $<1 \mu \mathrm{A}$, which are considerably smaller than usually obtained values, that are $>10$ $\mu \mathrm{A}$. Our approach generates photocurrents from waste which can be further tuned to reach standard photocurrent values.

\section{Conclusions}

A hydrodynamic cavitation method was designed for extracting the crystalline titanium and tungsten oxides from the cordierite surface of a spent SCR catalyst. High relative inlet pressure of $40 \mathrm{MPa}$ was applied to a divergent nozzle of $0.5 \mathrm{~mm}$ for obtaining high shear stresses of the submerged cavitating jets. Intensive micro- and nano-jets and shock waves acting on the particle surface of milled catalyst were provided along 200 cycles of hydrodynamic cavitation. 
SEM investigations performed on SCR catalyst sediment revealed the densely packed structure of metal oxide agglomerates (with a thickness of about $20 \mu \mathrm{m}$ ) at the surface of the cordierite layer and correspondent EDAX measurements indicated the high amount of Ti and W elements (31.4 wt.\% and $6.6 \mathrm{wt} . \%$, respectively) along a micro-area from the catalytic metal oxide region of the sample. The interface between the $\mathrm{WO}_{3}-\mathrm{TiO}_{2}$ region and the cordierite layer was investigated through EDAX mapping in SEM and measurements indicated a constant distribution of W and Ti elements over the entire cordierite micro-region under test.

With the help of BF-TEM investigations developed on a catalyst sample subjected to hydrodynamic cavitation processing, it was established a partial and complete separation of titanium and tungsten oxides from the cordierite support as agglomerations formed by nanoparticles with diameters of about 16-25 nm. The anatase tetragonal phase of $\mathrm{TiO}_{2}$ and cubic phase of $\mathrm{WO}_{3}$ were highlighted through HR-TEM and the measured inter-planar $d$ spacing has been confirmed by the diffraction peaks of the XRD measurements.

$\mathrm{WO}_{3}-\mathrm{TiO}_{2}$ nanocrystalline agglomerates, successfully separated from a spent SCR catalyst, were used in a photoelectrochemical device. Photocurrents as large as $0.5 \mu \mathrm{A}$ were determined, albeit extensive photoelectrochemical characterization is needed to elucidate the map out the working potential limits.

Supplementary Materials: The following are available online at http://www.mdpi.com/2075-4701/10/10/1307/s1, Figure S1: Measured reference electrode potential $(\mathrm{Ag} / \mathrm{AgCl})$ in $0.1 \mathrm{M} \mathrm{K}_{2} \mathrm{SO}_{4}$.

Author Contributions: Conceptualization, supervision and methodology, A.C., E.V. and S.N.S.; data curation, A.C., F.I.M., C.D. and S.N.S.; formal analysis, V.I., F.I.M., C.D. and C.M.; investigation and writing-original draft, E.V.; resources, A.C.; writing-review and editing, A.C., V.I. and S.N.S. All authors have read and agreed to the published version of the manuscript.

Funding: This work was supported by the Romanian Ministry of Research and Innovation under the PN-III-1.2-PCCDI-2017-0185 76PCCDI/2018 (ECOTECH-GMP) and PD 111/2018 (PECEC) within PNCDI III. This project has received funding from the European Union's Horizon 2020 Research and Innovation Programme under the Marie Skłodowska-Curie grant agreements No. 797781 (CALSOL). The results of this publication reflect only the authors' views and the Commission is not responsible for any use that may be made of the information it contains.

Conflicts of Interest: The authors declare no conflict of interest.

\section{References}

1. Kröcher, O. Selective Catalytic Reduction of NOx. Catalysts 2018, 8, 459. [CrossRef]

2. Li, J.; Chang, H.; Ma, L.; Hao, J.; Yang, R.T. Low temperature selective catalytic reduction of $\mathrm{NO}_{x}$ with $\mathrm{NH}_{3}$ over metal oxide and zeolite catalysts-A review. Catal. Today 2011, 175, 147-156. [CrossRef]

3. Zielińska, K.; Haratym, A. Environmental benefits of the SCR systems: A case study of the Lublin city transport. J. Ecol. Eng. 2017, 18, 202-207. [CrossRef]

4. Hosoya, M.; Kawada, Y.; Satao, S.; Shimoda, M. The study of $\mathrm{NO}_{\mathrm{x}}$ and PM Reduction Using Urea Selective Catalytic Reduction System for Heavy Duty Diesel Engine. SAE Tech. Pap. 2007, 1-8. [CrossRef]

5. Jaworski, P.; Jarosiński, S.; Capetillo, A.C.; Kapusta, Ł.J.; Ziółkowski, A.; Grzywnowicz, R. SCR systems for $\mathrm{NO}_{\mathrm{x}}$ reduction in heavy and light duty vehicles. Combust. Engines 2016, 164, 32-36.

6. Koebel, M.; Elsener, M.; Kleemann, M. Urea-SCR: A promising technique to reduce $\mathrm{NO}_{\mathrm{x}}$ emissions from automotive diesel engines. Catal. Today 2000, 59, 335-345. [CrossRef]

7. He, Y.; Ford, M.E.; Zhub, M.; Liu, Q.; Tumuluri, U.; Wu, Z.; Wachs, I.E. Influence of catalyst synthesis method on selective catalytic reduction (SCR) of $\mathrm{NO}$ by $\mathrm{NH}_{3}$ with $\mathrm{V}_{2} \mathrm{O}_{5}-\mathrm{WO}_{3} / \mathrm{TiO}_{2}$ catalysts. Appl. Catal. B Environ. 2016, 193, 141-150. [CrossRef]

8. Cao, Y.; Han, F.; Wang, M.; Han, L.; Zhang, C.; Wang, J.; Bao, W.; Chang, L. Regeneration of the Waste Selective Catalytic Reduction Denitrification Catalyst by Nitric Acid Washing. ACS Omega 2019, 4, 16629-16637. [CrossRef]

9. Kim, J.W.; Lee, W.G.; Hwang, I.S.; Lee, J.Y.; Han, C. Recovery of tungsten from spent selective catalytic reduction catalysts by pressure leaching. J. Ind. Eng. Chem. 2015, 28, 73-77. [CrossRef] 
10. Marberger, A.; Elsener, M.; Ferri, D.; Kröcher, O. $\mathrm{VO}_{\mathrm{x}}$ surface coverage optimization of $\mathrm{V}_{2} \mathrm{O}_{5}-\mathrm{WO}_{3} / \mathrm{TiO}_{2} \mathrm{SCR}$ catalysts by variation of the V loading and by aging. Catalyst 2015, 5, 1704-1720. [CrossRef]

11. Arce-Sarria, A.; Caicedo-Rosero, C.L.; Lara-Ramos, J.A.; Diaz-Angulo, J.; Machuca-Martínez, F. Experimental data on synthesis and characterization of $\mathrm{WO}_{3} / \mathrm{TiO}_{2}$ as catalyst. Data Brief 2019, 25, 104151-104152. [CrossRef] [PubMed]

12. Ramos-Delgado, N.A.; Hinojosa-Reyes, L.; Guzman-Mar, I.L.; Gracia-Pinilla, M.A.; Hernández-Ramírez, A. Synthesis by sol-gel of $\mathrm{WO}_{3} / \mathrm{TiO}_{2}$ for solar photocatalytic degradation of malathion pesticide. Catal. Today 2013, 209, 35-40. [CrossRef]

13. Soares, L.; Alves, A. Photocatalytic properties of $\mathrm{TiO}_{2}$ and $\mathrm{TiO}_{2} / \mathrm{WO}_{3}$ films applied as semiconductors in heterogeneous photocatalysis. Mater. Lett. 2018, 211, 339-342. [CrossRef]

14. Bayati, M.R.; Golestani-Fard, F.; Moshfeghd, A.Z.; Molaei, R. A photocatalytic approach in micro arc oxidation of $\mathrm{WO}_{3}-\mathrm{TiO}_{2}$ nanoporous semiconductors under pulse current. Mater. Chem. Phys. 2011, 128, 427-432. [CrossRef]

15. Argyle, M.D.; Bartholomew, C.H. Heterogeneous Catalyst Deactivation and Regeneration: A Review. Catalysts 2015, 5, 145-269. [CrossRef]

16. Qi, C.; Bao, W.; Wang, L.; Li, H.; Wu, W. Study of the $\mathrm{V}_{2} \mathrm{O}_{5}-\mathrm{W}_{\mathrm{O} 3} / \mathrm{TiO}_{2}$ Catalyst Synthesized from Waste Catalyst on Selective Catalytic Reduction of $\mathrm{NO}_{x}$ by $\mathrm{NH}_{3}$. Catalysts 2017, 7, 110. [CrossRef]

17. U.S. Environmental Protection Agency. Emerging Contaminant-Tungsten; 2010 EPA/505/F-10/004; U.S. Environmental Protection Agency: Washington, DC, USA, 2010.

18. Lia, M.; Liu, B.; Wang, X.; Yue, X.; Zheng, S.; Du, H.; Dreisinger, D.; Zhang, Y. A promising approach to recover a spent SCR catalyst: Deactivation by arsenic and alkaline metals and catalyst regeneration. Chem. Eng. J. 2018, 342, 1-8. [CrossRef]

19. Choi, I.-H.; Moon, G.; Lee, J.-Y.; Jyothi, R.K. Extraction of tungsten and vanadium from spent selective catalytic reduction catalyst for stationary application by pressure leaching process. J. Clean. Prod. 2018, 197, 163-169. [CrossRef]

20. Choi, I.-H.; Kim, H.-R.; Moon, G.; Jyothi, R.K.; Lee, J.-Y. Spent $\mathrm{V}_{2} \mathrm{O}_{5}-\mathrm{WO}_{3} / \mathrm{TiO}_{2}$ catalyst processing for valuable metals by soda roasting-water leaching. Hydrometallurgy 2018, 175, 292-299. [CrossRef]

21. Choi, I.H.; Moon, G.; Lee, J.-Y.; Jyothi, R.K. Hydrometallurgical processing of spent selective catalytic reduction (SCR) catalyst for recovery of tungsten. Hydrometallurgy 2018, 178, 137-145. [CrossRef]

22. Shang, X.; Hu, G.; He, C.; Zhao, J.; Zhang, F.; Xu, Y.; Zhang, Y.; Li, J.; Chen, J. Regeneration of full-scale commercial honeycomb monolith catalyst $\left(\mathrm{V}_{2} \mathrm{O}_{5}-\mathrm{WO}_{3} / \mathrm{TiO}_{2}\right)$ used in coal-fired power plant. J. Ind. Eng. Chem. 2012, 18, 513-519. [CrossRef]

23. Liu, Y.; Liu, Z.; Mnichowicz, B.; Harinath, A.V.; Li, H.; Bahrami, B. Chemical deactivation of commercial vanadium SCR catalysts in diesel emission control application. Chem. Eng. J. 2016, 287, 680-690. [CrossRef]

24. Li, X.; Li, J.; Peng, Y.; Chang, H.; Zhang, T.; Zhao, S.; Si, W.; Hao, J. Mechanism of arsenic poisoning on SCR catalyst of $\mathrm{CeW} / \mathrm{Ti}$ and its novel efficient regeneration method with hydrogen. Appl. Catal. B Environ. 2016, 184, 246-257. [CrossRef]

25. Dular, M.; Griessler-Bulc, T.; Gutierrez-Aguirre, I.; Heath, E.; Kosjek, T.; Klemencic, A.K.; Oder, M.; Petkovšek, M.; Racki, N.; Ravnikar, M.; et al. Use of hydrodynamic cavitation in (waste)water treatment. Ultrason. Sonochem. 2016, 29, 577-588. [CrossRef]

26. Sivakumar, M.; Pandit, A.B. Wastewater treatment: A novel energy efficient hydrodynamic cavitational technique. Ultrason. Sonochem. 2002, 9, 123-131. [CrossRef]

27. Jyoti, K.K.; Pandit, A.B. Hybrid cavitation methods for water disinfection: Simultaneous use of chemicals with cavitation. Ultrason. Sonochem. 2003, 10, 255-264. [CrossRef]

28. Jyoti, K.K.; Pandit, A.B. Effect of cavitation on chemical disinfection efficiency. Water Res. 2004, 38, $2249-2258$. [CrossRef]

29. Prajapat, A.L.; Gogate, P.R. Depolymerization of carboxymethyl cellulose using hydrodynamic cavitation combined with ultraviolet irradiation and potassium persulfate. Ultrason. Sonochem. 2019, 51, 258-263. [CrossRef]

30. Pathania, S.; Ho, Q.T.; Hogan, S.A.; McCarthy, N.; Tobin, J.T. Applications of hydrodynamic cavitation for instant rehydration of high protein milk powders. J. Food Eng. 2018, 225, 18-25. [CrossRef]

31. Li, K.; Woo, M.W.; Patel, H.; Metzger, L.; Selomulya, C. Improvement of rheological and functional properties of milk protein concentrate by hydrodynamic cavitation. J. Food Eng. 2018, 221, 106-113. [CrossRef] 
32. Find, J.; Emerson, S.C.; Krausz, I.M.; Moser, W.R. Hydrodynamic cavitation as a tool to control macro-, micro-, and nano-properties of inorganic materials. J. Mater. Res. 2001, 16, 3503-3513. [CrossRef]

33. Moser, W.R.; Marshik, B.J.; Kingsley, J.; Lemberger, M.; Willette, R.; Chan, A.; Sunstrom, J.E.; Boye, A. The synthesis and characterization of solid-state materials produced by high shear-hydrodynamic cavitation. J. Mater. Res. 1995, 10, 2322-2335. [CrossRef]

34. Zhou, W.; Chen, H.; Ou, L.; Shi, Q. Aggregation of ultra-fine scheelite particles induced by hydrodynamic cavitation. Int. J. Miner. Process. 2016, 157, 236-240. [CrossRef]

35. Kumar, K.S.; Moholkar, V.S. Conceptual design of a novel hydrodynamic cavitation reactor. Chem. Eng. Sci. 2007, 62, 2698-2711. [CrossRef]

36. Smoholkar, V.; Pandit, A.B. Modeling of hydrodynamic cavitation reactors: A unified approach. Chem. Eng. Sci. 2001, 56, 6295-6302. [CrossRef]

37. Ambulgekar, G.V.; Samant, S.D.; Pandit, A.B. Oxidation of alkylarenes to the corresponding acids using aqueous potassium permanganate by hydrodynamic cavitation. Ultrason. Sonochem. 2004, 11, 191-196. [CrossRef]

38. Wood, R.J.; Lee, J.; Bussemaker, M.J. A parametric review of sonochemistry: Control and augmentation of sonochemical activity in aqueous solutions. Ultrason. Sonochem. 2017, 38, 351-370. [CrossRef]

39. Hutli, E.; Nedeljkovic, S.M.; Radovic, N.A.; Bonyár, A. The relation between the high speed submerged cavitating jet behaviour and the cavitation erosion process. Int. J. Multiph. Flow 2016, 83, 27-38. [CrossRef]

40. Choi, J.-K.; Jayaprakash, A.; Chahine, G.L. Scaling of cavitation erosion progression with cavitation intensity and cavitation source. Wear 2012, 278, 53-61. [CrossRef]

41. Kim, W.T.; Kim, H.S.; Cho, S.B.; Lee, J.C.; Kim, S.B. Selective recovery of catalyst layer from supporting matrix of ceramic-honeycomb-type automobile catalyst. J. Hazard. Mater. 2010, 183, 29-34. [CrossRef]

42. Tao, P.; Sun, M.H.; Qu, S.C.; Song, C.W.; Li, C.; Yin, Y.Y.; Cheng, M.R. Effects of $\mathrm{V}_{2} \mathrm{O}_{5}$ and $\mathrm{WO}_{3}$ loadings on the catalytic performance of $\mathrm{V}_{2} \mathrm{O}_{5}-\mathrm{WO}_{3} / \mathrm{TiO}_{2}$ catalyst for SCR of $\mathrm{NO}$ with $\mathrm{NH}_{3}$. Glob. NEST J. 2017, 19, 160-166.

43. Wu, W.; Wang, C.; Bao, W.; Li, H. Selective reduction leaching of vanadium and iron by oxalic acid from spent $\mathrm{V}_{2} \mathrm{O}_{5}-\mathrm{WO}_{3} / \mathrm{TiO}_{2}$. Hydrometallurgy 2018, 179, 52-59. [CrossRef]

44. Peng, Y.; Li, J.H.; Si, W.Z.; Luo, J.M.; Wang, Y.; Fu, J.; Li, X.; Crittenden, J.; Hao, J.M. Deactivation and regeneration of a commercial SCR catalyst: Comparison with alkali metals and arsenic. Appl. Catal. B Environ. 2015, 168, 195-202. [CrossRef]

45. Chavez, C.A.; Toledo, J.; Cortes-Jacome, M.A. Chemical Quantification of Mo-S, W-Si and Ti-V by Energy Dispersive X-ray Spectroscopy; Intech Open: London, UK, 2012; p. $133 . \quad$ Available online: https://www.intechopen.com/books/x-ray-spectroscopy/chemical-quantification-of-mo-s-w-si-andti-v-by-energy-dispersive-x-ray-spectroscopy (accessed on 15 May 2020).

46. Lee, B.W.; Cho, H.; Shin, D.W. Characterization and De-NOX activity of binary $\mathrm{V}_{2} \mathrm{O}_{5} / \mathrm{T}_{\mathrm{i}} \mathrm{O}_{2}$ and $\mathrm{WO}_{3} / \mathrm{TiO}_{2}$, and ternary $\mathrm{V}_{2} \mathrm{O}_{5}-\mathrm{WO}_{3} / \mathrm{TiO}_{2}$ SCR catalysts. J. Ceram. Process. Res. 2007, 8, 203-207.

47. Kompio, P.G.W.A.; Bruckner, A.; Hipler, F.; Auer, G.; Loffler, E.; Grünert, W. A new view on the relations between tungsten and vanadium in $\mathrm{V}_{2} \mathrm{O}_{5} \mathrm{WO}_{3} / \mathrm{TiO}_{2}$ catalysts for the selective reduction of $\mathrm{NO}$ with $\mathrm{NH}_{3}$. J. Catal. 2012, 286, 237-247. [CrossRef]

48. Wang, C.; Yang, S.; Chang, H.; Peng, Y.; Li, J. Dispersion of tungsten oxide on SCR performance of $\mathrm{V}_{2} \mathrm{O}_{5} \mathrm{WO}_{3} / \mathrm{TiO}_{2}$ : Acidity, surface species and catalytic activity. Chem. Eng. J. 2013, 225, 520-527. [CrossRef]

49. Pini, M.; Salieri, B.; Ferrari, A.M.; Nowack, B.; Hischier, R. Human health characterization factors of nano-TiO for indoor and outdoor environments. Int. J. LCA 2016, 21, 1452-1462. [CrossRef]

50. Salieri, B.; Righi, S.; Pasteris, A.; Olsen, S.I. Freshwater ecotoxicity characterisation factor for metal oxide nanoparticles: A case study on titanium dioxide nanoparticle. Sci. Total Environ. 2015, 505, 494-502. [CrossRef] [PubMed]

51. Prabhua, S.; Cindrellaa, L.; Kwonb, O.J.; Mohanrajub, K. Photoelectrochemical and photocatalytic activity of $\mathrm{TiO}_{2}-\mathrm{WO}_{3}$ heterostructures boosted by mutual interaction. Mater. Sci. Semicond. Process. 2018, 88, 10-19. [CrossRef]

(C) 2020 by the authors. Licensee MDPI, Basel, Switzerland. This article is an open access article distributed under the terms and conditions of the Creative Commons Attribution (CC BY) license (http://creativecommons.org/licenses/by/4.0/). 